\title{
Influence of Dietary Supplementation of Ginger, Garlic and their Combination on Mycological Assessment of Quail Carcasses
}

\author{
Tamer Mohamed Gad ${ }^{1}$, Dalia El-Sayed El-Atriby ${ }^{2}$, Amany Mohamed Abd El-moaty ${ }^{1}$ \\ ${ }^{1}$ Veterinary Teaching Hospital, Veterinary Medicine Faculty, Mansoura University, Mansoura 35516, Egypt. \\ ${ }^{2}$ Specialized Internal Medicine Hospital, Mansoura University, Mansoura 35516, Egypt.
}

\section{ARTICLE HISTORY}

Received: 01.03.2021

Revised: 01.04.2021

Accepted: 02.04.2021

Correspondence to Tamer Gad; Tel. +201066583220; E-mail: tamer.gad83@gmail.com

\section{ABSTRACT}

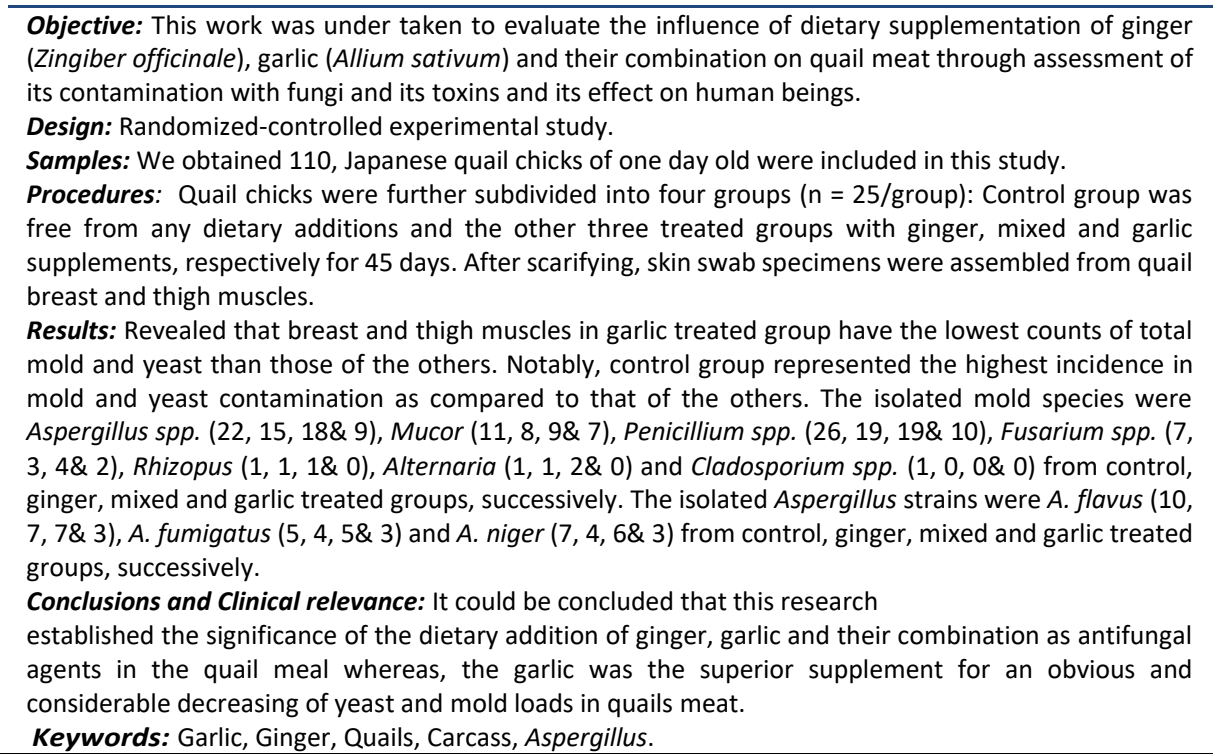

\section{INTRODUCTION}

Quails are considered an essential protein source that is characterized by good quality and cheap price. Quails meat is rich in essential amino acids (oleic, linoleic, palmitic and stearic), moreover, ratio of poly unsaturated fatty acids: saturated ones is 0.073 Genchev et al. [1]. Besides, meat of quails is a white meat has a little amount of fat and cholesterol, but it is rich in iron content Jaturasitha et al. [2]. Contamination of quail with fungus can exist in any stage from its production stages Wagner et al. [3].

Products of fungal growth which include mycotoxins and its metabolites carry a certain health risk for human through consumption of affected quails Darwish et al. [4]. Garlic and ginger are considered natural growth activators and can be effective substitutes for dominant artificial ones as antibiotics Demir et al. [5].

In-vitro, scientists indicated that the ginger extracts might limit free radicals quantity and lipids peroxidation $\boldsymbol{A l}$ Amin et al. [6] and have anti-diabetic characteristics Morakinyo et al. [7]. During cutting of garlic and under the action of allinase enzyme, cysteine sulfoxide in garlic can be changed into thiosulfinates which have powerful antibacterial and antifungal properties Hanieh et al. [8]. In native medicine, garlic is consumed as a spice for several years, because it has possessed a powerful activity against bacteria, fungi, parasites, viruses, oxidation, cholesterol, cancers and vasoconstriction Al-Shuwaili et al. [9]. Gingerol, gingerdiol and gingerdione are considered the most important components in ginger that have the eligibility to activate digestive enzymes, influence the microbial activity acting as antioxidants Dieumou et al. [10]. In this research we studied the effective antifungal activity of ginger, garlic and their combination and also, we evaluated the quality of meat in quail of supplemented groups in comparison with control one.

\section{MATERIALS AND METHODS}

Guide for the Care and Use of Laboratory Animals' announced by the Ethics Committee of Veterinary Medicine Faculty, Mansoura University (Permit numbers 20-17) was applied in animal rearing for all experiments. This experiment was performed from August-November, 2019, in Veterinary Teaching Hospital, Veterinary Medicine Faculty, Mansoura University at Dakahlia Governorate, Egypt

\subsection{Birds and experimental design:}

One hundred and ten, Japanese quail chicks had one day old were obtained from (Dakahlia Poultry Company, Egypt). 
All quails were reared in wire boxes, held in a well closed room $23 \mathrm{~h}$ under illumination and one hour of dim.

Birds were distributed into four groups ( $n=25$ per group): Control one was birds without any dietary supplements while the other three treated ones were ginger, mixed and garlic supplements, respectively. Quails in control group were supplied with a mercantile starter, constant feed devoid of any medicaments. Quails in supplemented groups had the same feed in addition to $14 \mathrm{~g} / \mathrm{Kg}$ commercial dried, ginger, garlic and their combination powders, respectively (El- Gomhoria Company, Egypt) as feed additive. The food and water were supplied without stoppage for each group of quails throughout the course of the

Experiment ( 45 days). The house temperature was kept at about $35^{\circ} \mathrm{C}$ during the first 3 days, then gradually decreased by $2{ }^{\circ} \mathrm{C}$ weekly until reached $24^{\circ} \mathrm{C}$ and kept constant until the end of the experiment.

\subsection{Samples collection}

Total number of birds ( $n=100$ ) were unfed for $5 \mathrm{~h}$ and slaughtered at the end of the experiment ( 45 days). Skin swab specimens were obtained by aseptic technique $\left(10 \mathrm{~cm}^{2}\right)$ from each quail carcass at 2 separate places (breast and thigh muscles). The samples were assembled in $9 \mathrm{ml}$ test tube that contains sterile buffered peptone water. After samples collection, from each quail, we obtained breast and thigh muscles independently and put in air-proof polyethylene boxes in relation to each dietary treatment and were chilled at $5+1^{\circ} \mathrm{C}$ for 2 days. All skin swab samples were taken under sterile conditions for mycological analysis.

\subsection{Mycological analysis}

The total mold and yeast counts were performed according to, APHA [11]. The assembled skin swab samples were mixed in $90 \mathrm{ml}$ of sterile buffered peptone water to give $10^{-1}$ dilution and were incubated for half an hour $/ 25^{\circ} \mathrm{C}$ and then tenfold dilutions were setted. Two parts of $0.1 \mathrm{ml}$ from every dilution were cultured in the same time on the surface of malt extract agar medium and Czapek-Dox agar with $5 \%$ $\mathrm{NaCl}$ and incubated aerobically away from light at $25^{\circ} \mathrm{C}$ /one week.

The mold and yeast counts were estimated by direct counting of the cultured agar plates. Mold counts were converted into base logarithms of colony forming units per gram of meat product samples (log cfu/g). Based on micro morphological characteristics, the predominant fungi in each specimen was distinguished to class level according to Raper et al. [12], Barnett et al. [13] and Samson et al. [14].

Table 1. Total mold count $\mathrm{cm}^{-2}$ in the examined surface of quail specimen: ( $\mathrm{n}=25$ each).

\begin{tabular}{l|llllll}
\multicolumn{1}{c}{ GRPUP } & \multicolumn{3}{c}{ BREAST } & \multicolumn{3}{c}{ THIGH } \\
& Min. & Max. & M \pm SE* & Min. & Max. & M \pm SE* \\
CONTROL & $1 \times 10^{2}$ & $1 \times 10^{3}$ & $3.9 \times 10^{2} \pm 0.88 \times 10^{2}$ & $0.95 \times 10^{2}$ & $3 \times 10^{3}$ & $2 \times 10^{2} \pm 1.15 \times 10^{2}$ \\
GINGER & $0.5 \times 10^{2}$ & $0.98 \times 10^{2}$ & $0.75 \times 10^{2} \pm 0.72 \times 10^{2}$ & $0.5 \times 10^{2}$ & $2.5 \times 10^{2}$ & $1.3 \times 10^{2} \pm 1.12 \times 10^{2}$ \\
MIXED $^{+}$ & $0.8 \times 10^{2}$ & $3.2 \times 10^{2}$ & $2.35 \times 10^{2} \pm 1.07 \times 10^{2}$ & $0.56 \times 10^{2}$ & $2.8 \times 10^{2}$ & $1.5 \times 10^{2} \pm 0.81 \times 10^{2}$ \\
GARLIC & $0.42 \times 10^{2}$ & $0.79 \times 10^{2}$ & $0.74 \times 10^{2} \pm 0.86 \times 10^{2}$ & $0.22 \times 10^{2}$ & $1.9 \times 10^{2}$ & $1 \times 10^{2} \pm 0.79 \times 10^{2}$
\end{tabular}

$* M \pm S E$, MEAN COUNT \pm STANDARD ERROR, + SIGNIFICANT DIFFERENCES $(P<0.05)$

Table 2. Total yeast count $\mathrm{cm}^{-2}$ in the examined surface of quail specimen: ( $\mathrm{n}=25 \mathrm{each}$ ).

\begin{tabular}{|c|c|c|c|c|c|c|}
\hline \multirow[t]{2}{*}{ GRPUP } & \multicolumn{3}{|c|}{ BREAST } & \multicolumn{3}{|c|}{ THIGH } \\
\hline & Min. & Max. & $\mathrm{M} \pm \mathrm{SE} *$ & Min. & Max. & $\mathrm{M} \pm \mathrm{SE} *$ \\
\hline CONTROL & $3.1 \times 102$ & $4.9 \times 103$ & $2.5 \times 103 \pm 0.68 \times 103$ & $1.9 \times 102$ & $9.6 \times 102$ & $4 \times 102 \pm 0.54 \times 102$ \\
\hline GINGER & $2.6 \times 102$ & $2.7 \times 102$ & $1 \times 102 \pm 0.37 \times 102$ & $0.98 \times 102$ & $1.89 \times 102$ & $1.14 \times 102 \pm 0.22 \times 102$ \\
\hline MIXED++ & $2.8 \times 102$ & $3.4 \times 102$ & $2.3 \times 102 \pm 0.93 \times 102$ & $1.8 \times 102$ & $2.42 \times 102$ & $2.2 \times 102 \pm 0.22 \times 102$ \\
\hline GARLIC & $1.7 \times 102$ & $2 \times 102$ & $1.05 \times 102 \pm 0.35 \times 102$ & $0.7 \times 102$ & $1.88 \times 102$ & $0.77 \times 102 \pm 0.13 \times 102$ \\
\hline
\end{tabular}

++ Means high significant differences $(p<0.01)$

Table 3. Incidence of molds and yeasts colonies identified from the examined surface of quail specimen: ( $n=25$ each).

\begin{tabular}{lllll} 
& MOLD & \multicolumn{3}{c}{ YEAST } \\
GROUPS & Breast & Thigh & Breast & Thigh \\
CONTROL & $832)$ & $10(40)$ & $8(32)$ & $11(44)$ \\
TOTAL & $8(32)$ & $10(40)$ & $8(32)$ & $11(44)$ \\
GINGER & $6(24)$ & $8(32)$ & $7(28)$ & $9(36)$ \\
MIXED & $7(28)$ & $9(36)$ & $6(24)$ & $10(40)$ \\
GARLIC & $5(20)$ & $4(16)$ & $5(20)$ & $8(32)$ \\
TOTAL & $18(24)$ & $21(28)$ & $18(24)$ & $27(36)$
\end{tabular}




\subsection{Statistical analysis}

All values are expressed as means $+\mathrm{SD}$, and all measurements were carried out in duplicates. Mold and yeast counts were converted into base logarithms of colony forming units per gram (log cfu/g). Statistical significance was evaluated using Tukey-Kramer HSD test. In all analyses, $\mathrm{p}<$ 0.05 was taken to indicate statistical significance using nonparametric ANOVA test (SPSS version 20) JMP statistical package, SAS Institute Inc., Cary, NC.

\section{RESULTS}

3.1. Dedication of mold and yeast number counts in quail carcasses

Quails looked well and rate of death did not represent any value throughout the experiment. Table 1 and 2 showed the influence of supplementation with $1.4 \%$ ginger, garlic and their mixed powders on mold and yeast counts during the research which had an important difference compared to control. Breast and thigh muscles in garlic treated group have the least numbers in total mold and yeast count compared to those of the others. Also, a considerable $(p<0.05)$ higher number of mold and yeast in breast and thigh specimens of both control and mixed supplemented groups as compared to those which were collected from both ginger and garlic supplemented ones, respectively.

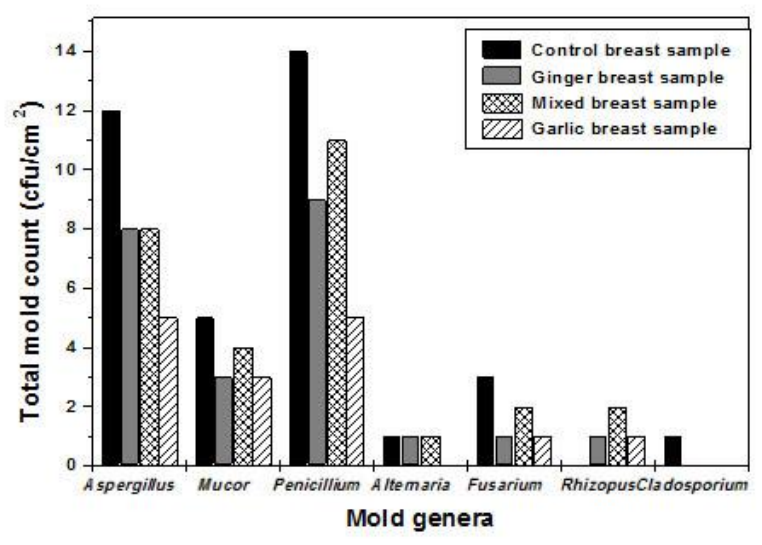

Figure 1. Incidence of the mold colonies identified from the examined breast specimen in control, ginger, mixed and garlic supplemented groups, respectively ( $n=25$ each).

\subsection{Prevalence of molds and yeasts in quail carcasses}

Results in Table 3 revealed that feeding of the birds on feeds treated with garlic, mixed and ginger powders, respectively resulted in reducing molds in their carcasses comparing to those fed on the ordinary control one. All control groups represented the highest incidence of molds with a percentage of 32 and $40 \%$, respectively in comparison with the other three treated ones which represented percentage 24 and 28\%, respectively. Also, All treated samples represented a lower yeast incidence $(24 \%$ for breast and $36 \%$ for thigh) compared to the control group (32\% for muscle of the breast and $44 \%$ for muscle of thigh). Through this work, in control group the isolated molds were 26
Penicillium isolates, 22 Aspergillus isolates, 11 Mucor isolates, 7 Fusarium isolates, 1 isolate for Rhizopus, Cladpsporium and Alternaria, (Table 4) (figures 1\&2). In contrast, the isolated molds in ginger, mixed and garlic treated ones, respectively were 15, 18 \&9 Aspergillus isolates, 8, 9\& 7 Mucor isolates, 19, 19\&10 Penicillium isolates, 3, 4\& 2 Fusarium isolates, 1 , 1\& 0 Rhizopus isolates and 1, 2\&0 Alternaria isolates and absence of Cladosporium.

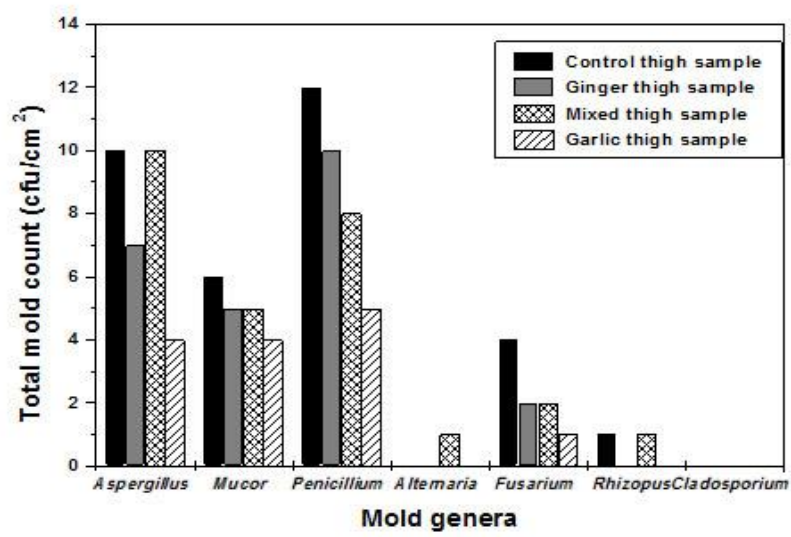

Figure 2. Incidence of mold colonies from the examined quail thigh specimens in control, ginger, mixed and garlic supplemented groups, respectively ( $\mathrm{n}=25$ each).

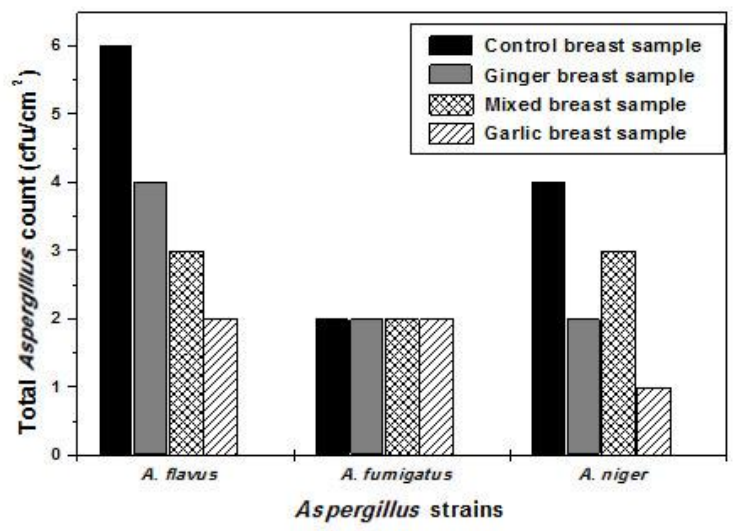

Figure 3. incidence of identified Aspergillus strains from the examined quails breast samples in in control, ginger, mixed and garlic supplemented groups, respectively ( $n=25$ each)

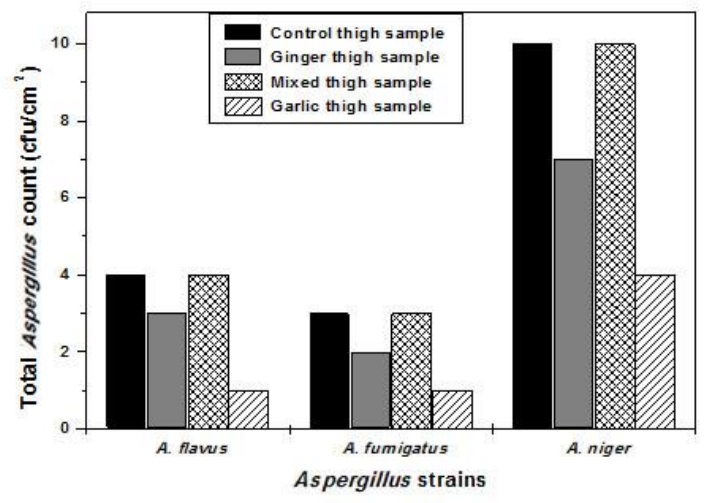

Figure 4. incidence of identified Aspergillus strains from the examined quails thigh samples in in control, ginger, mixed and garlic supplemented groups, respectively ( $n=25$ each) 


\subsection{Incidence of isolated Aspergillus strains}

Twenty-two (44\%) Aspergillus isolates in control group which were divided into: 10 (20\%) A. flavus, 5 (10\%) $A$. fumigatus and 7 (14\%) A. niger (Table 5) (figures 3\&4). In contrast, 42(28\%) of Aspergillus isolates in ginger, mixed and garlic treated ones were obtained as following: 17 (11.33\%) A. flavus, 12 (8\%) A. fumigatus and 13 (8.66\%) A. niger.

4. Table 4. Incidence of the mold colonies identified from the examined quail specimen: ( $n=25$ each).

\begin{tabular}{|c|c|c|c|c|c|c|c|c|c|c|}
\hline \multirow{3}{*}{ MOLD GENERA } & \multirow{2}{*}{\multicolumn{2}{|c|}{$\begin{array}{l}\text { CONTROL GROUP } \\
(\%)\end{array}$}} & \multirow{3}{*}{$\begin{array}{l}\text { TOTAL } \\
(\mathrm{N}=50)\end{array}$} & \multicolumn{6}{|c|}{ TREATED GROUPS (\%) } & \multirow{3}{*}{$\begin{array}{l}\text { TOTAL } \\
(\mathrm{N}=150)\end{array}$} \\
\hline & & & & \multicolumn{2}{|l|}{ Ginger } & \multicolumn{2}{|l|}{ Mixed } & \multicolumn{2}{|l|}{ Garlic } & \\
\hline & Breast & Thigh & & Breast & Thigh & Breast & Thigh & Breast & Thigh & \\
\hline ASPERGILLUS & $12(48)$ & $10(40)$ & $22(44)$ & $8(32)$ & $7(28)$ & $8(32)$ & $10(40)$ & $5(20)$ & $4(16)$ & $42(28)$ \\
\hline MUCOR & $5(20)$ & $6(24)$ & $11(22)$ & $3(12)$ & $5(20)$ & $4(16)$ & $5(20)$ & $3(12)$ & $4(16)$ & $24(16)$ \\
\hline PENICILLIUM & $14(56)$ & $12(48)$ & $26(52)$ & $9(36)$ & $10(40)$ & $11(44)$ & $8(32)$ & $5(20)$ & $5(20)$ & $48(32)$ \\
\hline ALTERNARIA & $1(4)$ & 0 & $1(2)$ & $1(4)$ & 0 & $1(4)$ & $1(4)$ & 0 & 0 & $3(0.5)$ \\
\hline FUSARIUM & $3(12)$ & $4(16)$ & $7(14)$ & $1(4)$ & 2 (8) & $2(8)$ & $2(8)$ & $1(4)$ & $1(4)$ & $9(1.5)$ \\
\hline RHIZOPUS & 0 & $1(4)$ & $1(2)$ & $1(4)$ & 0 & 0 & $1(4)$ & 0 & 0 & $2(0.33)$ \\
\hline CLADOSPORIUM & $1(4)$ & 0 & $1(2)$ & 0 & 0 & 0 & 0 & 0 & 0 & 0 \\
\hline
\end{tabular}

Table 5. Incidence of isolated Aspergillus strains from the examined quail specimens: ( $n=25$ each).

\begin{tabular}{|c|c|c|c|c|c|c|c|c|c|c|}
\hline \multirow{3}{*}{$\begin{array}{l}\text { ASPERGILLUS } \\
\text { STRAINS }\end{array}$} & \multirow{2}{*}{\multicolumn{2}{|c|}{$\begin{array}{l}\text { CONTROL GROUP } \\
(\%)\end{array}$}} & \multirow{3}{*}{$\begin{array}{l}\text { TOTAL } \\
(\mathrm{N}=50)\end{array}$} & \multicolumn{6}{|c|}{ TREATED GROUPS (\%) } & \multirow{3}{*}{$\begin{array}{l}\text { TOTAL } \\
(\mathrm{N}=150)\end{array}$} \\
\hline & & & & \multicolumn{2}{|c|}{ Ginger } & \multicolumn{2}{|l|}{ Mixed } & \multicolumn{2}{|l|}{ Garlic } & \\
\hline & Breast & Thigh & & Breast & Thigh & Breast & Thigh & Breast & Thigh & \\
\hline A. FLAVUS & $6(24)$ & $4(16)$ & $10(20)$ & $4(16)$ & $3(12)$ & $3(12)$ & $4(16)$ & $2(8)$ & $1(4)$ & $17(11.33)$ \\
\hline A. FUMIGATUS & $2(8)$ & $3(12)$ & $5(10)$ & $2(8)$ & $2(8)$ & $2(8)$ & $3(12)$ & $2(8)$ & $1(4)$ & $12(8)$ \\
\hline A. NIGER & $4(16)$ & $3(12)$ & $7(14)$ & $2(8)$ & $2(8)$ & $3(12)$ & $3(12)$ & $1(4)$ & $2(8)$ & $13(8.66)$ \\
\hline TOTAL & $12(48)$ & $10(40)$ & $22(44)$ & $8(32)$ & $7(28)$ & $8(32)$ & $10(40)$ & $5(20)$ & $4(16)$ & $\begin{array}{rr}42 & 2 \\
8\end{array}$ \\
\hline
\end{tabular}

\section{DISCUSSION}

Fungal contamination of quail muscles has a certain public health importance in the field of food control and hygiene because it results in food putrefaction which leads to mycotoxins production as recorded by Bryden [15]. The present research showed the occurrence of fungal contamination in carcasses which were taken from control and the other three treated groups. The previous results assured the theory that garlic has a powerful activity against fungi. Several studies have reported that the garlic decreases fungi contamination by reducing the oxygen uptake Szymona [16] decreasing of the pathogen growth, prevention of the lipids, proteins and nucleic acids synthesis Adetumbi et al. [17] and membranes damage Ghannoum [18]. Control group was highly contaminated with molds more than the other three treated groups, and thus resulting in a hazardous effect for human health.

These results showed obviously the decreasing of mold colonies number either in breast or thigh muscles which were taken from the three treated groups than those ofcontrolone. Ali et al. [19] documented that garlic addition in meals enhanced chicken meat quality under conditions of refrigeration and freezing.
Moreover, Fayed et al. [20] reported that garlic addition in meals reduced aerobic plate count and coliforms. Also, an earlier work showed that garlic supplementation to the feeds prevented the growth of aflatoxin producing fungi Meraj [21]. So, these results revealed the highest incidence of mold count of all groups in fresh quail carcasses because the conditions of wetness and warmness are suitable for fungal growth. Similarly, Mohsen [22] found that the total mold count/g showed the mean, minimum and maximum values which were $2.5 \times 10^{2} \pm 2 \times 10^{2},<10^{2}$ and $1 \times 10^{4}$ for fresh samples, but $1.2 \times 10^{2} \pm 1.0 \times 10^{2},<10$ and $2 \times 10^{2}$ for frozen ones, respectively. Besides, Mostafa [23], mentioned that the mean values of total mold count for fresh and frozen quail carcasses were $5.7 \times 10^{4}$ and, $6 \times 10^{4}$ respectively. Also, EIAbbassy [24] studied the mean values of total mold count for 80 quail carcasses inspected by surface technique after removal of skin which varied from $1 \times 10^{2}$ to $3 \times 10^{3}$ with a mean value of $4.65 \times 10^{2} \pm 1.87 \times 10^{2} / \mathrm{cm}^{2}$. Concerning to yeasts, the present work revealed a highly considerable lower count of yeasts in the breast and thigh specimens from group treated with garlic in comparison with that of the other three ones (control, ginger and mixed treated ones). This result was in consonance with Fayed et al. [20] who mentioned that yeast 
contamination was reduced in broiler chickens when fed on garlic. So, this work revealed the greater number of yeasts in the control and mixed groups than that in ginger and garlic treated ones with great high remarkable differences $(p<0.01)$. In an earlier study, the total yeast number was $\left(37 \times 10^{2}\right.$ and $42 \times 10^{2} / \mathrm{g}$ ) in chilled poultry for markets I and II, EI-Shora [25]. Another work, it was found that $9.4 \times 10^{4}$ (count/ g) of yeasts between specimens which were gathered from 45 sparrows after picking up of feathers in Egypt Yassien et al. [26]. Also, Rodríguez-Calleja et al. [27] reported that the preliminary level of yeasts on chilled stored rabbit carcasses was $3.46 \pm 0.32$ which grew quicker than the rest of microorganisms and became abundant at the terminal of rack life. In our work, carcasses of control group had a high count of mold genera than that in the other three treated ones including; Aspergillus species ( $A$. flavus was the most predominant molds, $A$. fumigatus and $A$. niger),Mucor, Penicillium spp., Alternaria, Fusarium spp., Rhizopus spp. and Cladosporium. Hechelman [28] isolated the most significant mold genera from meat, Aspergillus, Penicillium, Cladosporium, Alternaria, Fusarium, Mucor and Rhizopus in gradually decreased percentages. The former researches declared that the garlic has a powerful activity against Aspergillus species as mycotoxin producing molds Dankert et al. [29] and Tekeli et al. [30], Fusarium spp. and Rhizopus spp. Kutawa et al. [31].

Our results were in an agreement with Gad et al. [32] who studied the effect of dietary garlic addition on mycological evaluation of fresh and frozen quail carcasses and they found that garlic treated group was lower in total mold and yeast counts either breast or thigh muscles than those of control one, concerning that, the fungal contamination was higher in fresh quail carcasses than that of frozen ones and they isolated the following mold species: Aspergillus species ( $A$. flavus as the most predominant molds, A. fumigatus and $A$. niger), Mucor, Penicillium spp., Alternaria, Fusarium spp., Rhizopus spp. and Absidia from both groups. The antifungal effect of garlic is as a result of the presence of allicin or ajoene which has powerful antimicrobial and antifungal activities which hinders the activity of some enzymes that are essential for fungi. Thus, the decreasing of fungal contamination was noticed in this study. Oleforuh-Okoleh et al. [33] indicated that the ground ginger and garlic significantly $(p<0.05)$ influenced the carcass parts of the broilers. Though, contrary to Dieumou et al. [10] and Pourali et al. [34] who found that carcass parts were not affected by ginger or garlic, it is however in consonance with Raeesi et al. [35] who detected an essential effect on the carcass parts of broiler which fed on garlic. It has been reported that the diets containing ginger might stimulate lactic acid bacteria and reduce pathogenic ones like mesophilic aerobic, coliform and E. coli and mycotoxins producing molds and thus enhance the absorption of nutrients resulting in a better weight gain of the birds Tagoe et al. [36]. Our results were in an agreement with Karangiya et al. [37] who reported that garlic supplementation was the superior supplement in comparison to ginger and mixture of garlic and ginger. Also, Zeweil et al. [38] concluded that bee propolis, ginger or their mixture could effectively be used as a growth promoter and natural antioxidant in growing Japanese quail diets for improving feed conversion ratio, humeral immunity and to optimize lipid profile in blood serum and enhancing anti-oxidative status without negative effects on bird viability leading to unfavorable media for fungal growth.

\section{Conclusion}

It could be concluded that the garlic addition was the superior supplement in quails feeding which could enhance their carcass quality through its decreasing the mycological hazard and contamination.

\section{Acknowledgments}

This work was supported by Veterinary Teaching Hospital of Veterinary Medicine Faculty, Mansoura University, Egypt.

\section{Authors Contributions}

Tamer M. Gad: Revision of the whole article and shared as a corresponding author with the journal. Dalia E. El-Atriby: Collection of the samples, application of the practical study and scientific writing of the article. Amany M. Abd El-Moaty: Revision of the article and examining of the English language.

\section{Conflict of interest statement}

There is no any conflict of interest in the current research work.

\section{REFERENCES}

[1]. Genchev A, Mihaylova G, Ribarski S, Pavlov A, Kabakchiev M. Meat quality and composition in Japanese quails. Trakia Journal of Sciences. 2008;6:72-82.

[2]. Jaturasitha $S$, Thirawong $P$, Leangwunta $V$, Kreuzer $M$. Reducing toughness of beef from Bos indicus draught steers by injection of calcium chloride: Effect of concentration and time postmortem. Meat Science. 2004;68:61-9. https://doi.org/10.1016/j.meatsci.2004.02.004

[3]. Wagner KM, Schulz J, Kemper N. Examination of the hygienic status of selected organic enrichment materials used in pig farming with special emphasis on pathogenic bacteria. Porcine Health Management. 2018;4. https://doi.org/10.1186/s40813-018-0100-y

[4]. Darwish WS, Bayomi RME, El-Moaty AMA, Gad TM. Mould contamination and aflatoxin residues in frozen chicken meat-cuts and giblets. Japanese Journal of Veterinary Research. 2016;64(Supplement 2):S167-S71.

[5]. Demir E, Sarica ş, özcan MA, SulMez M. The use of natural feed additives as alternatives for an antibiotic growth promoter in broiler diets. British Poultry Science. 2003;44:S44-S5. https://doi.org/10.1080/00071660301944

[6]. Al-Amin ZM, Thomson M, Al-Qattan KK, Peltonen-Shalaby R, Ali M. Antidiabetic and hypolipidaemic properties of ginger ( Zingiber officinale) in streptozotocin-induced diabetic rats. British Journal of Nutrition. 2006;96:660-6. https://doi.org/10.1079/BJN20061849

[7]. Morakinyo AO, Akindele AJ, Ahmed Z. Modulation of antioxidant enzymes and inflammatory cytokines: possible mechanism of antidiabetic effect of ginger extracts. African Journal of Biomedical Research. 2011;14:195-202.

[8]. Hanieh H, Narabara K, Piao M, Gerile C, Abe A, Kondo Y. Modulatory effects of two levels of dietary Alliums on immune response and certain immunological variables, following immunization, in White Leghorn chickens. Animal Science Journal. 2010;81:673-80. https://doi.org/10.1111/j.1740-0929.2010.00798.x

[9]. Al-Shuwaili MA, Ibrahim El, Naqi Al-Bayati MT. Effect of dietary herbal plants supplement in turkey diet on performance and some blood biochemical parameters. Glob J Biosci Biotechnol. 2015;4:153-7. 
[10]. Dieumou FE, Teguia A, Kuiate JR, Tamokou JD, Fonge NB, Dongmo MC Effects of ginger (Zingiber officinale) and garlic (Allium sativum) essential oils on growth performance and gut microbial population of broiler chickens. Livestock research for rural development. 2009;21:2332.

[11]. APHA. Compendium of Methods for the Microbiological Examination of Foods. 4th Edn. Washington, USA: American Public Health Association; 2001.

[12]. Raper KB, Fennell KT. The Genus Aspergillus. The Williams and Wilkins Co., Baltimore, MD., USA., ISBN-13: 9780882751092. 1965:686.

[13]. Barnett HL, D. HD. Illustrated Genera of Imperfect Fungi.2nd Edn., Burgess Publishing Co., Minneapolis, MN., USA. 1978.

[14]. Samson RA, Hoekstra ES, Van Oorschot CAN. Introduction to foodborne fungi: Centraalbureau voor Schimmelcultures.; 1981.

[15]. Bryden WL. Mycotoxin contamination of the feed supply chain Implications for animal productivity and feed security. Animal Feed Science and Technology. 2012;173:134-58. https://doi.org/10.1016/j.anifeedsci.2011.12.014

[16]. Szymona M. Effect of phytoncides of Allium sativum on growth and respiration of certain pathogenic fungi. Acta microbiologica Polonica (1952). 1952;1:5-23.

[17]. Adetumbi M, Javor GT, Lau BH. Allium sativum (garlic) inhibits lipid synthesis by Candida albicans. Antimicrobial Agents and Chemotherapy. https://doi.org/10.1128/AAC.30.3.499

[18]. Ghannoum MA. Studies on the Anticandidal Mode of Action of Allium sativum (Garlic). Microbiology. 1988;134:2917-24. https://doi.org/10.1099/00221287-134-11-2917

[19]. Ali FH, Zahran DA. Effect of growth enhancers on quality of chicken meat during cold storage. Advance Journal of Food Science and Technology. 2010;2:219-26.

[20]. Fayed RH, Abeer H, Razek A, Jehan M. Effect of dietary garlic supplementation on performance, carcass traits, and meat quality in broiler chickens. Parameters. 2011;100:1000-4.

[21]. Meraj ICA. Effect of garlic and neem leaves supplementation on the performance of broiler chickens. 1998.

[22]. Mohsen MEA. Studies on the microbiological status of slaughtered quail. 2005.

[23]. Mostafa H. Further studies on the meat quality of game birds. 2001.

[24]. El-Abbassy MT. Mycological aspects of quail carcasses with atrial to improve their sanitary status. MV Sc. 2007.

[25]. El-Shora SE. Studies on the sanitary status of Kalyobia meat, poultry and fish cool stores. M.V.Sc. Thesis, Faculty of Veterinary Medicine, Zagazig University, Benha Branch, Moshtohor, Egypt. 1990.

[26]. Yassien N, Darwish A, El-Sherif A, El-Daly E. Food borne fungi in sparrows. Vet Med J Giza. 1991;39:201-7.

[27]. Rodríguez-Calleja JM, García-López M-L, Santos JA, Otero A. Development of the aerobic spoilage flora of chilled rabbit meat. Meat Science. 2005;70:389-94 https://doi.org/10.1016/j.meatsci.2005.01.009

[28]. Hechelman H. A general discussion of yeasts and molds. Fleischerei. 32. 1981:107-10.

[29]. Dankert J, Tromp TF, De Vries H, Klasen HJ. Antimicrobial activity of crude juices of Allium ascalonicum, Allium cepa and Allium sativum. Zentralblatt fur Bakteriologie, Parasitenkunde, Infektionskrankheiten und Hygiene Erste Abteilung Originale Reihe A: Medizinische Mikrobiologie und Parasitologie. 1979;245:229-39.

[30]. Tekeli A, Kutlu HR, Celik L. Effects of Z. officinale and propolis extracts on the performance, carcass and some blood parameters of broiler chicks. Current Research in Poultry Science. 2011;1:12-23. https://doi.org/10.3923/crpsaj.2011.12.23

[31]. Kutawa AB, Danladi MD, Haruna A. Regular article antifungal activity of garlic (allium sativum) extract on some selected fungi. Journal of Medicinal Herbs and Ethnomedicine. 2018;4:12-4.

[32]. Gad TM, Elkenany RM, Eltaysh RA. Influence of Dietary Garlic Supplementation on Mycological Assessment of Fresh and Frozen Quail Carcasses. Journal of Applied Sciences. 2019;19:421-6. https://doi.org/10.3923/jas.2019.421.426

[33]. Oleforuh-Okoleh VU, Chukwu GC, Adeolu Al. Effect of ground ginger and garlic on the growth performance, carcass quality and economics of production of broiler chickens. Glob J Biosci Biotechnol. 2014;3:2259.
[34]. Pourali M, Mirghelenj SA, Kermanshahi H. Effects of garlic powder on productive performance and immune response of broiler chickens challenged with Newcastle Disease Virus. Global Veterinaria. 2010;4:616-21.

[35]. Raeesi M, Hoseini-Aliabad SA, Roofchaee A, Shahneh ZA, Pirali S. Effect of periodically use of garlic (allium sativum) powder on performance and carcass characteristics in broiler chickens. World Academy of Science, Engineering and Technology. 2010;44:1223-9.

[36]. Tagoe DNA, Nyarko HD, Akpaka R. A Comparison of the Antifungal Properties of Onion (Allium cepa), Ginger (Zingiber officinale) and Garlic (Allium sativum) against Aspergillus flavus, Aspergillus niger and Cladosporium herbarum. Research Journal of Medicinal Plant. 2011;5(3):281-7. https://doi.org/10.3923/rjmp.2011.281.287

[37]. Karangiya VK, Savsani HH, Patil SS, Garg DD, Murthy KS, Ribadiya NK, et al. Effect of dietary supplementation of garlic, ginger and their combination on feed intake, growth performance and economics in commercial broilers. Veterinary World. 2016;9(3):245-50. https://doi.org/10.14202/vetworld.2016.245-250

[38]. Zeweil h, abd el rahman m, Desoky W, Abu hafsa S, Abdulhamid A. Effects of ginger and bee propolis on the performance, carcass characteristics and blood constituents of growing japanese quail. Egyptian Poultry Science Journal. 2016;36:143-59. https://doi.org/10.21608/epsj.2016.33238 